\title{
PATOGENESIS HAWAR DAUN BIBIT PINUS MERKUSII YANG DISEBABKAN OLEH PESTALOTIA THEAE DI PESEMAIAN
}

\author{
Sutarman ${ }^{1}$, Soetrisno Hadi ${ }^{2}$, Ani Suryani ${ }^{2}$, Achmad $^{2}$, Asep Saefuddin ${ }^{2}$
}

\begin{abstract}
Pathogenesis of Needle Blight of Pinus merkusii Seedlings Incited by Pestalotia theae in The Nursery. The objectives of the study were to clarify the mechanism by which Pestalotia theae incites the disease and the defense mechanism of the pine seedling against the attack by the pathogen. The germination tube, $2.9 \mu \mathrm{m}$ in diameter, produced by the germinating conidiospore penetrated the leaf cells via the stomata, which were wider in diameter. The pathogen was able to produce pectinolytic and cellulolytic enzymes required for the degrading of the host cell wall components. The epidermis was covered by a thick cuticulae layer. The activity of the peroxidase reduced in the cotyledon, the primary leaf and in the secondary leaf decreased, when the seedlings were $1-2,2-3$, and $>3$ month old.
\end{abstract}

Key words: Pinus merkusii, needle blight, Pestalotia theae, symptom, pathogenesis, defense mechanism

\section{PENDAHULUAN}

Mekanisme serangan patogen Pestalotia theae dan mekanisme pertahanan bibit Pinus merkusii terhadap patogen penyebab penyakit Hawar Daun bibit $P$. merkusii tersebut di pesemaian di Indonesia relatif belum banyak terungkap, meskipun dampak penyakit tersebut sudah mulai dirasakan oleh pengelola pesemaian di wilayah kerja Perum Perhutani khususnya di Jawa Barat dan Jawa Tengah.

Pestalotia spp. yang menyerang kelapa, teh, dan beberapa jenis tanaman lainnya pada umumnya menginfeksi melalui luka atau lubang alami (Semangun, 2000). Proses infeksi yang terjadi pada daun bibit pinus, sebagaimana dikemukakan Agrios (1997), menunjukkan bahwa patogen ini mampu melakukan penetrasi ke dalam sel inang. Pada fase tersebut jamur harus mempenetrasi dinding sel yang mengandung senyawa selulosa dan pektin dalam rangka pengambilan nutrisi bagi kebutuhan hidupnya (Graffin, 1993). Untuk itu diperlukan enzim-enzim selulolitik dan pektinolitik yang dihasilkan jamur untuk mendegradasi selulosa dan pektin (Goodman dkk., 1986). Proses hidrolisis pektin di lamela tengah mengakibatkan degradasi jaringan pada tepi lesio (Barmore dkk., 1984). Menurut Bailey dan Pessa (1990) enzim yang bekerja pada bahan pektik sebagai polisakarida struktural di lamela tengah dan dinding sel primer tanaman tingkat tinggi ini dihasilkan oleh banyak jenis mikroorganisme.

Gejala penyakit pada bibit $P$. merkusii dimulai pada kotiledon pada bibit yang berumur sekitar 2 bulan, diikuti oleh daun pertama pada umur 2-3 bulan, kemudian daun jarum pada umur 3-4 bulan (Sutarman dkk., 2001). Hal ini menunjukkan adanya perbedaan perkembangan gejala di antara komponen tajuk bibit pinus pada umumnya yang sekaligus, sebagaimana dikemukakan Mirov (1967), sebagai akibat adanya perbedaan metabolit sejalan dengan perbedaan umur dan pertumbuhan daun bibit pinus. Pada pertumbuhan komponen tajuk yang berbeda, diduga adanya perbedaan dalam metabolisme lanjut senyawa fenolik yang berperan dalam mekanisme pertahanan bibit. Melalui peran aktivitas polifenoloksidase, senyawa-senyawa fenolik tersebut akan dioksidasi menjadi senyawa yang lebih berbahaya bagi patogen (Martyn dkk., 1979; Agrios, 1997). Peroksidase berperan dalam pengoksidasian senyawa fenolik dan metabolit lain dalam rangka penyusunan komponen dinding sel (Ebermann \& Lickl, 1985). Hasil penelitan Achmad (1996) menunjukkan adanya kecenderungan perbedaan dan/atau penurunan aktivitas polifenoloksidase dan peroksidase bibit pinus dari umur 1 bulan sampai umur 2 bulan. Di lain pihak hasil penelitiannya juga menunjukkan adanya peningkatan ketahanan bibit terhadap serangan patogen lodoh dari umur 0 sampai 8 minggu setelah penaburan benih sejalan dengan peningkatan kandungan lignin jaringan hipokotil.

Penelitian ini bertujuan untuk: (a) mengetahui mekanisme serangan patogen melalui pengamatan perkecambahan konidiospora dan pengujian aktivitas enzim-enzim selulolitik dan pektinolitik yang dihasilkan oleh patogen, serta (b) mengetahui mekanisme pertahanan oleh bibit $P$. merkusii terhadap serangan patogen melalui pengamatan struktur anatomi jaringan daun, percobaan respons bibit umur rawan (periode penyerangan) dan pengujian aktivitas polifenoloksidase dan peroksidase.

\footnotetext{
${ }^{1}$ Dosen Fakultas Kehutanan Institut Pertanian Malang, Jl. Soekarno- Hatta, Malang

${ }^{2}$ Dosen Program Pascasarjana Institut Pertanian Bogor, Kampus IPB Darmaga Bogor
} 
Tabel 1. Umur bibit dan macam daun bibit $P$. merkusii yang diuji aktivitas enzim selulolitik dan pektinolitiknya

\begin{tabular}{cll}
\hline \multirow{2}{*}{$\begin{array}{c}\text { Umur } \\
\text { bibit } \\
(\text { BSP) }\end{array}$} & \multicolumn{2}{c}{ Macam daun yang diuji aktivitas enzimnya } \\
\cline { 2 - 3 } & Keadaan Bibit Sehat & Keadaan Bibit Sakit \\
\hline $0^{1)}$ & Kotiledon & Kotiledon \\
\hline 1 & Kotiledon dan epikotil & \\
\hline 2 & Kotiledon, daun tunggal, daun jarum & Kotiledon \\
\hline 3 & Kotiledon, daun tunggal, daun jarum & Kotiledon dan daun tunggal \\
\hline 4 & Kotiledon, daun tunggal, daun jarum & Kotiledon, daun tunggal, daun jarum \\
\hline 5 & Daun tunggal dan daun jarum & Kotiledon, daun tunggal, daun jarum \\
\hline T) & Umur 0 bulan setelah penyapihan (BSP) adalah & saat bibit akan dilakukan penyapihan \\
atau bibit berumur 2 minggu setelah penaburan & \\
2) & Merupakan campuran bakal daun tunggal dan bakal daun jarum.
\end{tabular}

\section{Respons bibit terhadap serangan patogen}

Percobaan dilakukan dengan tujuan untuk mengetahui kemungkinan adanya perbedaan respons bibit pada berbagai umur, yaitu 1 sampai 4 bulan sesudah penyapihan (BSP), terhadap infeksi oleh patogen. Respons yang diamati adalah gejala penyakit dan perkembangannya. Bibit yang sehat diinkubasi di rumah plastik selama 2 minggu dan dilindungi dengan fungisida Dithane $\mathrm{M}-45$ dari gangguan patogen. Bibit yang berumur 1, 2, 3, dan 4 bulan diinokulasi dengan kondiospora patogen yang kemudian diinkubasi selama 4 minggu. Percobaan faktor tunggal dengan 4 taraf umur bibit ini disusun dalam Rancangan Acak Lengkap (RAL) dengan 4 ulangan. Satu satuan percobaan terdiri atas 20 bibit $P$. merkusii. Untuk menunjukkan perbedaan respons dalam bentuk gejala, maka Indeks Penyakit ditentukan tiap minggu selama 4 minggu.

Indeks Penyakit terhadap bibit yang diuji tiap minggu dilakukan dengan menggunakan rumus dan penetapan skor dengan kriteria gejala seperti yang digunakan Sutarman dkk. (2003).

\section{Struktur anatomi daun $P$. merkusii}

Pengamatan dilakukan terhadap struktur anatomi daun dengan titik berat pada bagian tempat masuk patogen ke dalam jaringan daun seperti stomata dan komponen struktural daun lainnya yang dapat berfungsi untuk pertahanan mekanik. Untuk mengamati struktur anatomi daun, terlebih dahulu dibuat irisan melintang daun bibit pada umur sekitar 2-3 bulan dengan prosedur Sass (1958).

\section{Aktivitas polifenoloksidase dan peroksidase}

Berdasarkan penelitian pendahuluan selama 1-4 BSP, bibit berada dalam kondisi yang rentan terhadap penyakit. Oleh karena itu pengujian terhadap aktivitas polifenoloksidase dan peroksidase dilakukan untuk bibit sejak saat penyapihan sampai 5 BSP, yaitu masa kotiledon sehat relatif sudah tidak dijumpai lagi. Pengujian dilakukan terhadap aktivitas kedua macam enzim tersebut (Srivastava, 1987) yang diperoleh dari kotiledon, daun tunggal, dan dari daun jarum bibit $P$. merkusii baik yang sehat maupun yang sakit. Secara keseluruhan diperoleh tiga komponen tajuk (kotiledon, daun pertama, dan daun jarum) dengan keadaan yang berbeda yaitu: umur bibit dan komponen tajuk bibit serta keadaan daun yaitu yang sehat dan sakit yang aktivitas kedua macam enzimnya diuji, seperti tertera pada Tabel 1.

Adapun untuk penentuan sampel yang diuji, mula-mula dipilih secara acak kelompok bibit (dalam rak) untuk tiap kelompok umur $(0,1,2,3,4$, dan 5 bulan) dan dari tiap kelompok umur bibit dipisahkan antara bibit sakit (skor 0) dan yang sehat (skor 1) berdasarkan kriteria penentuan gejala seperti yang digunakan Sutarman dkk. (2003).

Seperti tertera pada Tabel 1, maka diperoleh 24 macam perlakuan. Selanjutnya perlakuan tersebut disusun dalam suatu percobaan faktor tunggal dengan menggunakan Rancangan Acak Lengkap (RAL) yang diulang sebanyak dua kali. 
Tabel 2. Kadar glukosa dan aktivitas poligalakturonase yang dihasilkan dalam filtrat biakan $P$. theae pada beberapa macam media

\begin{tabular}{cll}
\hline Media & $\begin{array}{l}\text { Kadar Glukosa } \\
(\mathrm{mg} / \mathrm{l})\end{array}$ & $\begin{array}{l}\text { Aktivitas poligalakturonase } \\
(\mu \mathrm{mol} / \mathrm{g})\end{array}$ \\
\hline Pachlewsky & $0,5306 \pm 0,0030$ & $0,8687 \pm 0,1695$ \\
\hline Pestalotia-Pachlewsky & $0,4200 \pm 0,0030$ & $0,8863 \pm 0,0847$ \\
\hline CMS & $0,4519 \pm 0,0060$ & $1,5914 \pm 0,0648$ \\
\hline Pestalotia-CMS & $0,4530 \pm 0,0045$ & $1,6055 \pm 0,4936$ \\
\hline CMS-P. merkusii & $0,5668 \pm 0,1565$ & $1,3834 \pm 0,3690$ \\
\hline Pestalotia-CMS-P. merkusii & $0,6466 \pm 0,0196$ & $1,5209 \pm 0,4238$ \\
\hline
\end{tabular}

\section{HASIL DAN PEMBAHASAN}

\section{Perkecambahan konidiospora}

Dari inkubasi pada media Pachlewsky cair selama 12 jam pada suhu kamar, dapat diketahui tahap-tahap proses perkecambahan konidiospora, dengan rata-rata diameter tabung kecambahnya sebesar $2,88 \mu \mathrm{m}( \pm 0,59 \mu \mathrm{m})$, sebagai berikut:

a. Persiapan perkecambahan selama 4 jam masa inkubasi (JMI) pertama; sesudah 4 JMI sel keempat (atau 2 sel sesudah pedisel) agak menggelembung dan menjadi makin transparan;

b. Permulaan terbentuknya tabung kecambah yang terjadi selama 4-5 JMI yaitu berupa tonjolan pada salah satu atau kedua sisi sel keempat tersebut dengan panjang tabung kecambah $5,95 \mu \mathrm{m} \pm$ $1,36 \mu \mathrm{m}$ pada $5 \mathrm{JMI}$;

c. Pertumbuhan dan percabangan tabung kecambah yang dimulai sekitar 6 JMI dengan panjang tabung kecambah pada $6,8,10$, dan $12 \mathrm{JMI}$ masing-masing adalah $8,43 \mu \mathrm{m} \pm 2,22 \mu \mathrm{m}$; $12,40 \mu \mathrm{m} \pm 4,64 \mu \mathrm{m} ; 32,74 \mu \mathrm{m} \pm 16,02 \mu \mathrm{m}$; dan $56,11 \mu \mathrm{m} \pm 21,66 \mu \mathrm{m}$. Setelah $12 \mathrm{JMI}$, percabangan tabung kecambah membentuk anyaman hifa yang setelah 24 JMI menjadi kompleks jalinannya.

Hubungan pertumbuhan panjang tabung kecambah konidiospora $P$. theae tersebut dengan waktu yaitu dari 5 sampai 12 jam lama inkubasi ini, dapat dinyatakan dalam persamaan regresi (1):

$Y=59,24-18,16 X+1,55 X^{2} \quad\left(R^{2}=99,7 \%\right)$

dengan $\mathrm{Y}=$ panjang tabung kecambah, $\mathrm{X}=$ masa inkubasi (selama 5-12 jam)

\section{Aktivitas enzim penghidrolisis komponen dinding} sel daun

Berdasarkan hasil analisis ragam (taraf $5 \%$ ) diketahui bahwa tidak terdapat perbedaan baik dalam aktivitas "filter paper-ase" maupun aktivitas poligalakturonase yang dihasilkan oleh $P$. theae pada media tumbuh yang berbeda.

Rerata hasil pengujian aktivitas "filter paperase" dan poligalakturonase yang dihasilkan oleh P. theae tersebut disajikan pada Tabel 2 .

\section{Respons bibit umur awal terhadap serangan patogen}

Perkembangan Indeks Penyakit pada berbagai umur bibit dapat dilihat pada Gambar 2 .

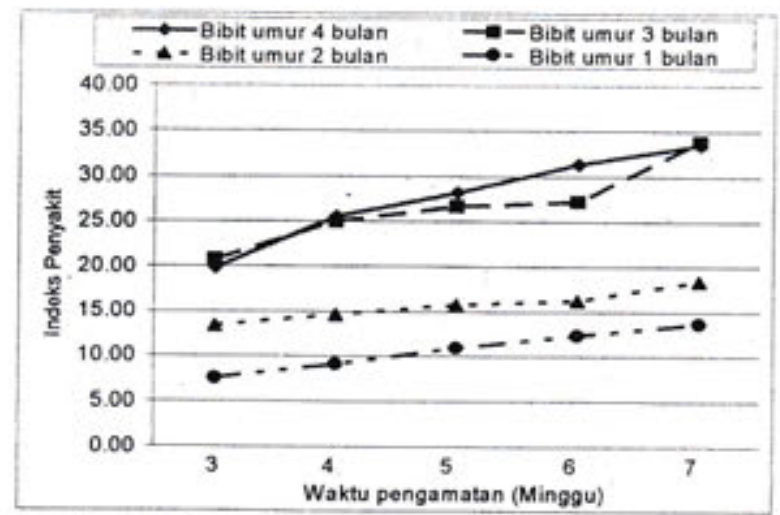

Gambar 2. Indeks Penyakit bibit $P$. merkusii berumur $1,2,3$, dan 4 bulan yang terserang $P$. theae 3 sampai 7 minggu setelah inokulasi (MSI)

Sejak awal pengamatan terdapat perbedaan yang nyata dalam Indeks Penyakit antara bibit berumur 3 dan 4 bulan dan bibit berumur 1 dan 2 
Tabel 3. Ukuran lubang stomata kotiledon, daun pertama, dan daun jarum bibit $P$. merkusii berumur 2-3 bulan setelah penyapihan

\begin{tabular}{llr}
\hline Komponen tajuk & Panjang lubang stomata & Lebar lubang stomata \\
\hline Kotiledon & $21,70 \mu \mathrm{m} \pm 2,89 \mu \mathrm{m}$ & $8,31 \mu \mathrm{m} \pm 1,21 \mu \mathrm{m}$ \\
Daun pertama & $26,29 \mu \mathrm{m} \pm 1,36 \mu \mathrm{m}$ & $10,18 \mu \mathrm{m} \pm 1,84 \mu \mathrm{m}$ \\
Daun jarum & $23,81 \mu \mathrm{m} \pm 1,28 \mu \mathrm{m}$ & $8,43 \mu \mathrm{m} \pm 1,28 \mu \mathrm{m}$ \\
\hline
\end{tabular}

bulan. Pada akhir pengamatan ( $7 \mathrm{MSI})$, Indeks Penyakit bibit berumur 3 dan 4 bulan masingmasing adalah 33,86 dan 33,48 , yang menunjukkan bahwa bibit tersebut lebih rentan dibandingkan dengan bibit berumur 1 dan 2 bulan, yaitu dengan Indeks Penyakit berturut-turut sebesar 13,65 dan 18,42 . Di lain pihak pada 3-7 MSI Indeks Penyakit bibit berumur 2 bulan sejak terdapat perbedaan nyata lebih besar dibandingkan dengan Indeks Penyakit bibit berumur 1 bulan. Hal ini menunjukkan bahwa bibit berumur 2 bulan lebih rentan dibandingkan dengan yang berumur 1 bulan.

\section{Struktur anatomi daun bibit $P$. merkusii}

Pada struktur anatomi kotiledon, daun pertama, dan daun jarum bibit $P$. merkusii umur 5 bulan setelah penyapihan, berdasarkan irisan melintang, terlihat bahwa dinding sel epidermis ketiga komponen tajuk tersebut tampak tebal. Di antara sel-sel mesofil daun dijumpai saluran resin, yang dikelilingi oleh sel-sel epitel. Jaringan pengangkut ganda yang masing-masing terdiri atas floem dan xylem, terletak di tengah-tengah. Potongan melintang kotiledon dan daun pertama membentuk bidang menyerupai segitiga, sedang daun jarum membulat. Pada ketiga macam komponen tajuk bibit $P$. merkusii ini tampak epidermis daun memiliki lapisan kutikula yang bervariasi ketebalannya pada ketiga komponen tajuk pada umur sekitar 3-5 bulan yaitu dari 2,8 $\mu \mathrm{m} \pm$ $0,27 \mu \mathrm{m}$ sampai $5,4 \mu \mathrm{m} \pm 0,55 \mu \mathrm{m}$. Sel penutup stoma berada agak di bawah lapisan epidermis.

Adapun ukuran lubang stoma daun jarum, daun pertama, dan kotiledon bibit $P$. merkusii umur 2-3 bulan, yang merupakan umur rawan bagi bibit untuk mulai dapat terserang penyakit, dapat dilihat pada Tabel 3.

\section{Aktivitas polifenoloksidase dan peroksidase}

Hasil analisis ragam menunjukkan bahwa tidak terdapat perbedaan nyata antara aktivitas polifenoloksidase dari berbagai macam daun, tetapi terdapat perbedaan yang nyata dalam aktivitas peroksidase antara daun dengan kondisi berbeda tersebut. Rerata aktivitas kedua macam enzim tersebut tertera pada Tabel 4 , dan dengan pola aktivitas yang ditunjukkan pada Gambar 3 dan 4 .

Aktivitas polifenoloksidase di antara ketiga macam daun dan di antara daun yang sehat dan yang sakit menunjukkan pola yang berbeda (Gambar 3). Hal serupa terjadi pada aktivitas peroksidase (Gambar 4). Terutama pada kotiledon, tampak adanya perbedaan respons bibit terhadap serangan patogen yang ditunjukkan oleh aktivitas peroksidase pada 1, 2, dan 4 BSP serta aktivitas polifenoloksidase pada 4 BSP yang relatif tinggi dibandingkan pada bibit sehat.

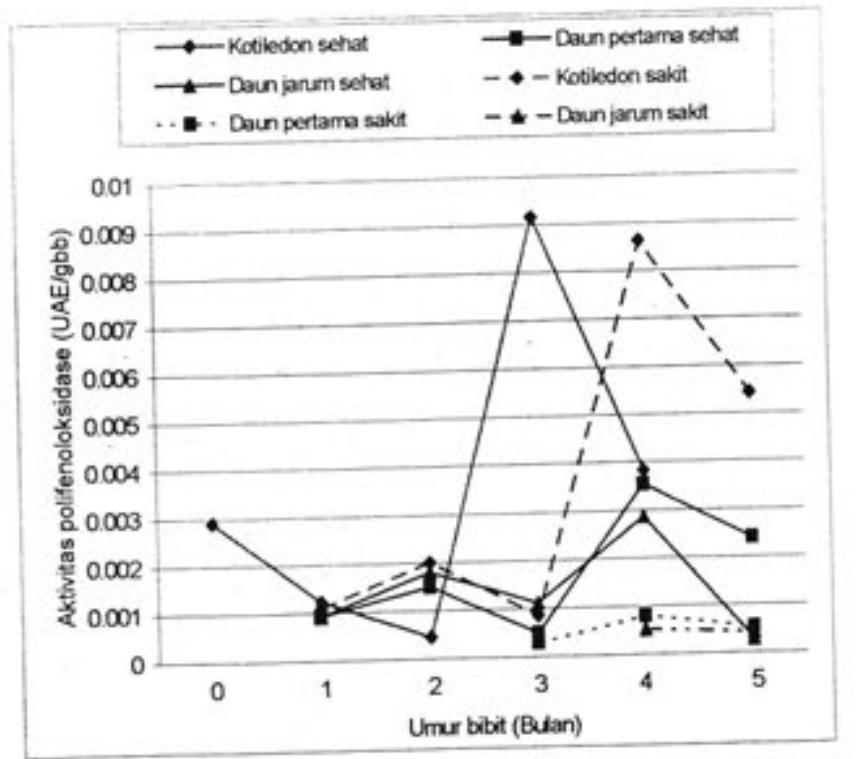

Gambar 3. Aktivitas polifenoloksidase dari kotiledon, daun pertama, dan daun jarum sehat dan sakit pada bibit $P$. merkusii berumur $0-5$ bulan setelah penyapihan (BSP) 
Tabel 4. Aktivitas polifenoloksidase dan peroksidase dari berbagai komponen tajuk bibit $P$. merkusii pada umur $0-5$ bulan setelah penyapihan (BSP)

\begin{tabular}{|c|c|c|c|c|c|}
\hline \multirow{3}{*}{$\begin{array}{l}\text { Umur } \\
\text { bibit } \\
\text { (bulan) }\end{array}$} & \multirow{3}{*}{$\begin{array}{l}\text { Komponen } \\
\text { tajuk }\end{array}$} & \multicolumn{4}{|c|}{ Aktivitas enzim (UAE/gbb) } \\
\hline & & \multicolumn{2}{|c|}{ Polifenoloksidase } & \multicolumn{2}{|l|}{ Peroksidase $^{3)}$} \\
\hline & & Sehat & Sakit & Sehat & Sakit \\
\hline $0^{11}$ & Kotiledon & 0,002900 & $-^{21}$ & $\begin{array}{l}1,1600 \\
\text { abcde }\end{array}$ & -- \\
\hline \multirow[t]{2}{*}{1} & Kotiledon & 0,001225 & 0,001090 & 0,7300 bcdef & 1,3267 abcd \\
\hline & Epikotil & 0,000925 & $\cdots$ & $0,5467 \mathrm{def}$ & $-\cdots$ \\
\hline \multirow[t]{3}{*}{2} & Kotiledon & 0,000450 & 0,002000 & $1,4429 a b c$ & 1,7472 a \\
\hline & Daun pertama & 0,001490 & $-\cdots$ & 0,7430 bcdef & $\cdots$ \\
\hline & Daun jarum & 0,001795 & $\ldots$ & 0,4489 def & $-\cdots$ \\
\hline \multirow[t]{3}{*}{3} & Kotiledon & 0,009155 & 0,000860 & 0,7940 bcdef & 0,4667 def \\
\hline & Daun pertama & 0,000490 & 0,000285 & 0,3914 ef & 0,4920 def \\
\hline & Daun jarum & 0,001115 & $-\cdots$ & 0,5830 bcdef & - \\
\hline \multirow[t]{3}{*}{4} & Kotiledon & 0,003830 & 0,008630 & 0,3720 ef & $\begin{array}{l}1,0530 \\
\text { abcdef }\end{array}$ \\
\hline & Daun pertama & 0,003550 & 0,000800 & 0,7424 cdef & 0,4370 def \\
\hline & Daun jarum & 0,002860 & 0,000540 & 0,2660 ef & $0,2500 \mathrm{f}$ \\
\hline \multirow[t]{3}{*}{5} & Kotiledon & $\cdots$ & 0,005435 & $\cdots$ & $1,5134 \mathrm{ab}$ \\
\hline & Daun pertama & 0,002400 & 0,000515 & $\begin{array}{l}0,9830 \\
\text { abcdef }\end{array}$ & 0,7200 bedef \\
\hline & Daun jarum & 0,000290 & 0,000420 & $\begin{array}{l}0,9855 \\
\text { abcdef }\end{array}$ & $0.2455 \mathrm{f}$ \\
\hline
\end{tabular}

1) Umur pada saat penyapihan atau 2 minggu setelah penaburan

2) ... = menunjukkan pengukuran aktivitas polifenoloksidase dan peroksidase tidak dapat dilakukan

${ }^{3)}$ Nilai yang diikuti huruf yang sama tidak berbeda pada taraf $5 \%$ berdasarkan uji jarak berganda Duncan

Secara umum gejala penyakit muncul pada bibit berumur sekitar 2 bulan setelah penyapihan (BSP). Menurut Mirov (1967) terdapat perbedaan macam dan kadar metabolit sejalan dengan perbedaan umur dan pertumbuhan daun bibit pinus. Sebagaimana hasil penelitian terhadap bibit berumur $1-4$ bulan, diketahui bahwa umur 3 bulan merupakan umur bibit yang lebih rentan dibandingkan dengan umur 1 dan 2 bulan. Namun demikian bukan berarti umur 1-2 bulan tidak dapat terserang. Kenyataannya di lapang, bibit berumur sekitar 1 bulan dapat juga terserang oleh $P$. theae yaitu pada masa kotiledon terbentuk. Hal tersebut sejalan dengan fakta bahwa dari daun yang sehat aktivitas peroksidase kotiledon menurun pada 1 'BSP $(0,7300$ UAE/gbb $)$ dibandingkan dengan 0 BSP atau saat penyapihan
(1,1600 UAE/gbb), sedang aktivitas polifenoloksidase menurun sampai bibit berumur 2 BSP $(0,00045$ $\mathrm{UAE} / \mathrm{gbb})$, dari umur 1 BSP $(0,001225 \mathrm{UAE} / \mathrm{gbb})$, dan dari bibit saat penyapihan (0,0029 UAE/gbb). Oleh karenanya bibit berumur dari 2 sampai 3 BSP mulai menunjukkan gejala sakit. Setelah peningkatan perkembangan penyakit pada bibit berumur $3 \mathrm{BSP}$, aktivitas polifenoloksidase kembali menurun menjadi $0,00383 \mathrm{UAE} / \mathrm{gbb}$ pada umur $4 \mathrm{BSP}$, demikian juga aktivitas peroksidase turun dari 1,4429 UAE/gbb pada bibit berumur 2 BSP menjadi $0,7940 \mathrm{UAE} / \mathrm{gbb}$ waktu bibit berumur 3 BSP serta $0,3720 \mathrm{UAE} / \mathrm{gbb}$ ketika bibit berumur 4 BSP.

Daun pertama mulai menunjukkan gejala setelah bibit berumur 2 BSP dan dapat dikatakan bahwa daun pertama terserang segera setelah 


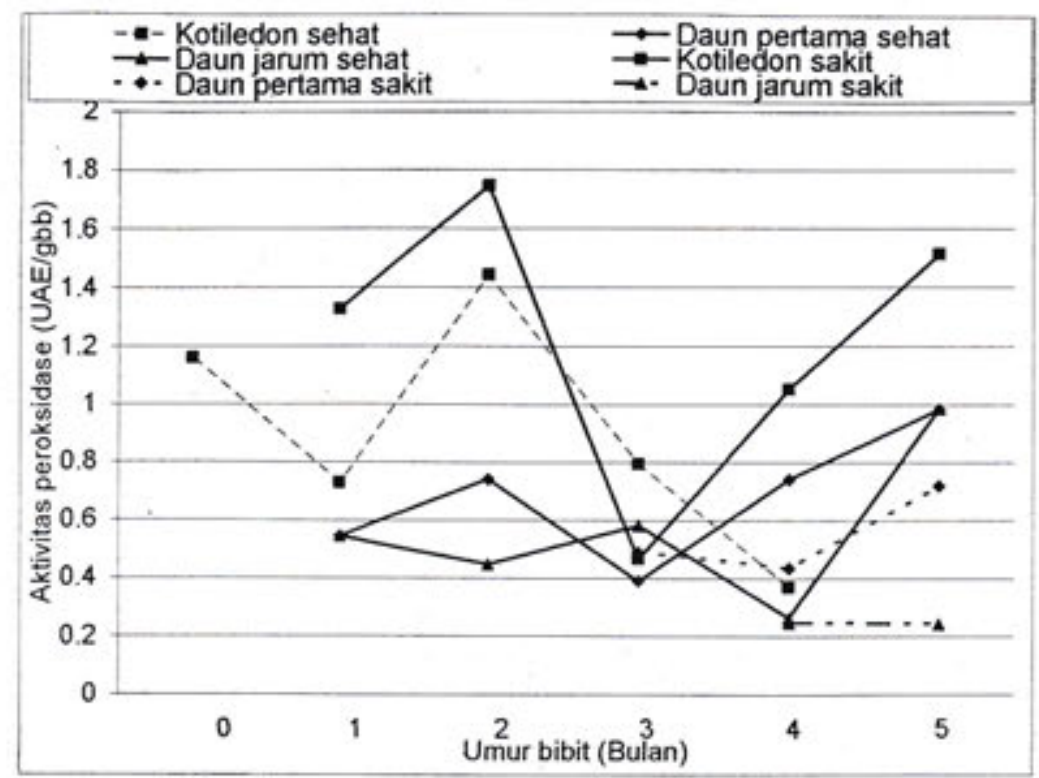

Gambar 4. Aktivitas peroksidase dari kotiledon, daun tinggal, dan daun jarum sehat dan sakit pada bibit $P$. merkusii berumur $0-5$ bulan setelah penyapihan (BSP)

kotiledon terserang, dan jarang sekali daun pertama tersebut terserang lebih dahulu dari kotiledon. Aktivitas polifenoloksidase dan peroksidase daun pertama menurun waktu bibit berumur 3 BSP. Pada bibit berumur 4 BSP aktivitas kedua enzim ini meningkat lagi.

Perkecambahan merupakan proses penting yang menentukan keberhasilan patogen dalam melakukan serangan. Pada media Pachlewsky, tabung kecambah sudah mencapai $56,11 \mu \mathrm{m}$ setelah 12 jam inkubasi. Bila diasumsikan inisiasi yang dirangsang oleh eksudat dan kelembaban yang mendukung di stoma pada ujung daun mendorong konidia untuk berkecambah dan tabung kecambah masuk ke dalam ruang stoma, maka langkah berikutnya adalah dikeluarkannya enzim-enzim yang diperlukan untuk menguraikan komponen dinding sel. Selulase dan pektinase yang dilepaskan konidia, seperti pada Blumeria graminis (Suzuki dkk. 1998), diduga berperan penting dalam penempelan tabung kecambah konidia jamur pada permukaan tanaman inang.

Epidermis daun $P$. merkusii yang relatif tebal dan keras diduga menyebabkan jamur patogen ini tidak mampu menginfeksi langsung melalui epidermis, kecuali adanya pelukaan. Berbagai hasil penelitian yang terangkum oleh Semangun (2000) menunjukkan bahwa Pestalotia sp. menginfeksi melalui luka atau lubang alami. Ukuran lubang stomata rupanya bukan menjadi hambatan bagi tabung kecambah untuk masuk ke dalamnya. Ukuran lubang stoma kotiledon $21,7 \mu \mathrm{m} \times 8,31 \mu \mathrm{m}$, lubang stoma daun pertama $26,29 \mu \mathrm{m} \times 10,18 \mu \mathrm{m}$, dan lubang stoma daun jarum 23,81 $\mu \mathrm{m} \times 8,34 \mu \mathrm{m}$ semuanya adalah jauh lebih besar dibandingkan dengan diameter tabung kecambah yaitu $2,88 \pm 0,59$ $\mu \mathrm{m}$; sementara itu, seperti ditunjukkan oleh Hidayat (1996), sel penutup ada bagian dinding sel yang tidak terlignifikasi turut berfungsi dalam proses membuka dan menutupnya stoma, memungkinkan tabung kecambah dapat masuk ke ruang antarsel untuk memulai infeksinya. Dengan demikian maka peran enzim selulolitik dan pektinolitik atau salah satu di antaranya menjadi penting bagi aktivitas serangan patogen pada daun.

Gejala hawar yang tampak pada daun bibit pinus menunjukkan telah terjadi infeksi. Untuk melaksanakan aktivitas penetrasi dan infeksi, maka jamur harus menguraikan senyawa selulosa dan pektin sebagai komponen penyusun dinding sel-sel di bawah epidermis dengan bantuan enzim ekstraselular selulolitik dan pektinolitik yang dihasilkan jamur itu sendiri (Goodman dkk. 1986; Barmore dkk. 1984; Griffin 1993).

Meskipun secara statistik pada taraf $5 \%$ tidak nyata, tetapi bukan berarti $P$. theae tidak memiliki kemampuan untuk menghasilkan kedua macam enzim tersebut. Menurut Achmad (1996) tidak terdeteksinya aktivitas poligalakturonase melalui teknik iodometri 
adalah karena kuantitas bahan sumber pektatnya kurang memadai.

Dari pengujian aktivitas selulase filtrat biakan $P$. theae, diketahui bahwa kadar glukosa pada perlakuan media Pachlewsky ternyata lebih tinggi daripada perlakuan media Pachlewsky yang ditumbuhkan patogen. Hal ini menunjukkan bahwa patogen menggunakan gula sederhana yang tersedia pada media Pachlewsky tersebut untuk pertumbuhannya.

Pada daun jarum, aktivitas polifenoloksidase dan peroksidase relatif lebih rendah daripada aktivitas enzim tersebut dari kotiledon dan daun pertama. Diduga hal ini berkaitan dengan adanya penekanan aktivitasnya oleh hormon pertumbuhan yang diproduksi bibit seperti auxin dalam rangka perpanjangan sel pada daun muda (Goodwin dan Erwee 1981; Woolhouse dan Jenkins 1983). Selama kurun waktu awal pertumbuhan tersebut aktivitas pemanjangan dan pertambahan sel relatif tinggi pada daun jarum. Menurut Devlin (1975), auxin dapat menekan aktivitas kedua enzim tersebut. Diduga penekanan ini juga berlaku terhadap aktivitas enzimenzim yang dihasilkan oleh jamur patogen.

Pada daun yang pertumbuhannya optimal, senyawa fenolik sebagai hasil metabolit sekunder melalui jalur Asam Sikimik (Taiz dan Zeiger, 1991) akan mengalami oksidasi dengan melibatkan enzim polifenoloksidase yang menghasilkan senyawa toksik terhadap jamur patogen dan enzim peroksidase yang menghasilkan radikal-radikal bebas senyawa fenolik sederhana untuk pembentukan lignin (lignifikasi) yang berguna untuk pertahanan terhadap invasi patogen (Agrios 1997; Miyazawa dkk. 1998). Menurut Eisensmith dkk. (1982) kerentanan daun akan makin menurun dengan makin bertambahnya umur daun. Pada periode umur bibit $P$. merkusii 0-8 minggu, makin tua umur bibit, kadar lignin makin meningkat (Achmad 1996). Kondisi ini berlaku secara umum pada perkembangan tiap bagian tubuh bibit pinus.

Sementara itu kutikula pinus yang tebal, dengan ukuran berkisar 2,8-5,4 $\mu \mathrm{m}$ pada umur 3-5 bulan, sebagaimana dikemukakan Doster dan Schnathorst (1985), merupakan salah satu mekanisme fisik dalam pertahanan terhadap serangan patogen.

Baik aktivitas polifenoloksidase maupun peroksidase terutama dari kotiledon daun sakit, yang mencerminkan respons bibit dalam hal pertahanan secara aktif, lebih tinggi daripada aktivitas yang dari kotiledon sehat.
Berkaitan dengan hal tersebut, ada dua macam mekanisme pertahanan bibit pinus yaitu: (i) secara pasif dengan aktivitas polifenoloksidase dan peroksidase komponen tajuk bibit dari umur 0-5 BSP yang dalam keadaan sehat, serta (ii) secara aktif dengan aktivitas polifenoloksidase dan peroksidase komponen tajuk bibit dari umur 0-5 BSP yang dalam keadaan sakit.

Pada pertahanan pasif secara kimia ini, aktivitas kedua macam enzim tersebut menunjukkan pola khas bibit pinus. Pada kotiledon misalnya, peningkatan aktivitas polifenoloksidase secara drastis pada bibit berumur 3 BSP sebelum kembali turun pada bibit berumur 4 BSP (Gambar 3) dan peningkatan aktivitas peroksidase pada bibit berumur 2 BSP sebelum kembali turun pada bibit berumur 4 BSP (Gambar 4) menjadikan kotiledon yang belum terinfeksi pada bibit berumur 2-3 bulan menjadi lebih tahan. Itulah sebabnya sebagaimana ditunjukkan pada data distribusi nisbah kotiledon terinfeksi (Tabel 4), sampai pada 13-14 MSP masing-masing nisbah infeksi 5,70 dan 6,45 (dari total 8,00 ) yang berarti rata-rata nisbah kotiledon sehat 2,30-1,55. Kondisi serupa dapat terjadi pada daun pertama dengan penurunan aktivitas kedua macam enzim tersebut pada bibit berumur sekitar 3 BSP dan penurunan berikutnya terjadi setelah bibit berumur 4 BSP yang merupakan saat rentan bagi bibit terhadap serangan patogen.

Pada pertahanan bibit secara aktif, respons bibit terhadap serangan patogen ditunjukkan oleh peningkatan aktivitas kedua macam enzim tersebut. Pada kotiledon, aktivitas polifenoloksidase cenderung pada bibit sakit lebih tinggi di bandingkan dengan pada yang tidak terinfeksi pada bibit berumur 2 BSP (Gambar 3) dan secara nyata aktivitas peroksidase meningkat pada bibit berumur 1-2 BSP (Gambar 4). Adapun pada daun pertama, dengan umur yang relatif pendek dan akan gugur setelah bibit berumur lebih dari 5 bulan, pola aktivitas polifenoloksidase dan peroksidase pada bibit sakit tidak tampak perbedaannya dibandingkan dengan pada bibit yang sehat.

Sejalan dengan fakta yang menunjukkan adanya mekanisme pertahanan bibit secara aktif tersebut, terjadi peningkatan aktivitas kedua macam enzim tersebut lebih pada daun terinfeksi dan prekursor senyawa-senyawa fenolik menginduksi sintesis polifenoloksidase pada jaringan yang sakit (Jennings dkk. 1969 dan Grec, 1992). Senyawasenyawa fenolik tersebut akan dioksidasi dengan bantuan aktivitas polifenoloksidase menjadi senyawa 
yang lebih berbahaya bagi patogen (Martyn dkk. 1979). Di lain pihak senyawa fenolik akan dioksidasi dengan bantuan peroksidase yang menghasilkan produk bagi penyusunan komponen dinding sel (Ebermann dan Lickl 1985).

Aktivitas polifenoloksidase relatif kecil dan fluktuasinya tidak memiliki pola yang khas dari bibit berumur 0-5 BSP. Menurut Lewis (1975, diacu oleh Achmad 1996), fluktuasi aktivitas polifenoloksidae tidak memiliki hubungan dengan umur semai pinus Loblolly yang dipelajarinya. Keliszewska-Rokicka (1983, diacu oleh Achmad 1996) juga menunjukkan kecilnya aktivitas polifenoloksidase pada Pinaceae sebagaimana banyak dilaporkan pada tumbuhan berbiji terbuka.

\section{SIMPULAN}

Serangan Pestalotia theae dalam proses patogenesis dimulai dengan perkecambahan konidiospora. Tabung kecambah yang pada media Pachlewsky cair berdiameter $2,88 \mu \mathrm{m} \pm 0,59 \mu \mathrm{m}$, mungkin untuk masuk kedalam jaringan daun melalui stoma daun yang berukuran jauh lebih besar. Terhadap uji aktivitas enzim-enzim selulolitik dan pektinolitik yang diproduksi oleh patogen, ternyata tidak terdeteksi dengan menggunakan media Pachlewsky, CMS, dan CMS-daun pinus.

Pertahanan bibit $P$. merkusii terhadap serangan $P$, theae adalah dengan adanya epidermis dengan lapisan kutikula yang tebal yang mencegah penetrasi langsung permukaan daun, dan produksi peroksidase yang besar aktivitasnya tergantung pada umur dan macam daun komponen tajuk.

Interaksi inang-patogen dalam proses patogenesis mempengaruhi waktu timbulnya gejala, yaitu pada kotiledon bibit berumur sekitar 1-2 bulan, pada daun pertama sekitar 2 bulan, dan umur lebih dari 3 bulan pada daun jarum. Timbul dan perkembangan gejala sejalan dengan kerentanan bibit $P$. merkusii yang dipengaruhi oleh penurunan aktivitas peroksidase yang diproduksi dalam beberapa macam daun komponen tajuk bibit.

\section{DAFTAR PUSTAKA}

Achmad. 1996. Mekanisme serangan patogen dan pertahanan inang serta pengendalian hayati penyakit lodoh pada Pinus merkusii (disertasi). Bogor: Institut Pertanian Bogor, Program Pascasarjana.
Agrios G.N. 1997. Plant pathology. Edisi ke-4. San Diego: Academic Press.

Atlas RM. 1993. Handbook of microbiological media. London: CRC Press.

Bailey MJ, Pessa E. 1990. Strain and process for production of polygalacturonase. Enzyme Microb. Technol. 12: 266-271

Barmore CR, Snowden SE, Brown, GE. 1984. Endopolygalacturonase from Valencia orange infected with Diplodia natalensis. Phytopathology 74: $735-737$

Devlin RM. 1975. Plant physiology. Edisi ke-3. New York: D. van Nostrand Co.

Doster MA, Schnathorst WC. 1985. Effects of leaf maturity and cultivar resistance on development of the powdery mildew fungus on grapevines. Phytopathology 74: 572-577

Ebermann R, Lickl E. 1985. The possible rate of peroxidase isozymes in the infection of English oak by Loranthus europaeus. Phytopathology 75: 1102-1104

Eisensmith SP, Sjulin TM, Jones AL, Cress CE. 1982. Effect of leaf age and inoculum concentration on infection of sour cherry by Coccomyces hiemalis. Phytopathology 72: 574577

Goodman NR, Kiraly Z, Zaitlin M. 1986. The biochemistry and physiology of infectious plant disease. Bagian wall composition and metabolism. New Jersey: D. Van Nostrand Co. hlm. 107-150.

Goodwin PB, Erwee MG. 1981. Hormonal influences on leaf growth. Di dalam Dale JE, Milthorpe FI, editor. The growth and functioning of leaves. Proceedings of a symposium held prior to the Thirtheen International Botanical Congress at The University of Sydney; Sidney; 18-20 August 1981. London: Cambridge University Press, hlm. 207-232.

Grec L. 1992. Physiology of the diseased plant. Di dalam: Sebanek J., editor. Plant physiology. 
Amsterdam: Elsevier Science Publishing Co. hlm. $422-432$

Griffin DH. 1993. Fungal physiology. New York, Chicester, Brisbane, Toronto, Singapore: J. Wiley.

Hidayat EB. 1996. Anatomi tumbuhan berbiji. Bandung: Penerbit ITB.

Jennings PH, Brannaman BL, Zscheile FP. 1969. Peroxidase and polyphenol oxidase activity associated with Helminthosporium leaf spot of maize. Phytopathology 59: 963-967.

Kieliszewska-Rokicka B. 1983. Polymorphism and function of some oxidizing enzymes of Scots pine (Pinus sylvestris L.). Arboretum Kornickie 28: 237-259

Martyn RD, Samuelson DA, Freeman TE. 1979. Ultrastructural localization of polyphenoloxidase activity in leaves of healthy and diseased waterhyacinth. Phytopathology 69: 1278-1287

Mirov T. 1967. Pinus. New York: The Ronald Press.

Miyazawa J, Abe K, Hasegawa H. 1998. Allosteric regulation of cell wall-bound peroxidase and induction of acquired resistance to tomato wilt disease by 4-hydroxybenzoic hydrazide. Ann. Phytopathol. Soc. Japan 64: 16-23.

Sass JE. 1958. Botanical microtechnique. Ameslowa: Iowa State College Press.
Semangun H. 2000. Penyakit-penyakit tanaman perkebunan di Indonesia. Yogyakarta: Gadjahmada Univ. Press.

Srivastava SK. 1987. Peoxidase and polyphenoloxidase in Brassica juncea plants infected with Machrophomina phaseolina in disease resistance. Phytopathology 120: 249-254.

Suzuki S, Komiya Y, Mitsui T, Tsuyumu S, Kunoh H, Carver TLW, dan Nicholson RL. 1998. Release of cell wall degrading enzymes from conidia of Blumeria graminis on artificial substrate. Ann. Phytopathol. Soc. Japan 64: 160-167.

Sutarman, Achmad, Hadi S. 2001. Penyakit hawar daun bibit pimus merkusii di pesemaian. Agritek 9: 1419-1427.

Sutarman, Achmad, Hadi S, Suryani A, Saefuddin A. 2003. Analisis kerugian penyakit hawar daun bibit Pinus merkusii di pesemaian (dalam penerbitan)

Taiz L, Zeiger E. 1991. Plant physiology. New York: The Benjamin/Cummings Publishing Company.

Woolhouse HW, Jenkins GI. 1983. Physiological responses, metabolic changes, and regulation during leaf senescene. Di dalam: Dale JE, Milthorpe FI, editor. The growth and functioning of leaves. Proceedings of a symposium held prior to the Thirtheen International Botanical Congress at The University of Sydney. Sydney; 18-20 August 1981. London: Cambridge University Press. hlm. 449-488. 